\title{
Leadership styles and leadership outcomes in nursing homes: a cross-sectional analysis
}

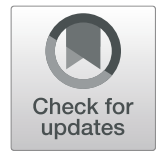

Joris Poels $^{1^{*}}$ (D), Marc Verschueren ${ }^{1,2}$, Koen Milisen $^{1,3}$ and Ellen Vlaeyen ${ }^{1}$

\begin{abstract}
Background: Although leadership is considered as a key factor in health care, leadership styles and outcomes in nursing homes often remain a black box. Therefore, this study explored leadership styles and leadership outcomes of head nurses and directors of nursing (DoN) in nursing homes based on well-defined leadership concepts.

Methods: A multicenter cross-sectional analysis was conducted on baseline data of an ongoing cohort study comprising a convenience sample of nursing home staff $(n=302)$. Leadership styles and leadership outcomes of head nurses and DoN were measured through the rater form of the Multifactor Leadership Questionnaire 5X (MLQ5X). Based on the Full Range of Leadership Model, the MLQ-5X visualizes transformational (relation and change focused), transactional (task-focused) and passive-avoidant (absence of leadership) leadership styles. Scores of head nurses and DoN for leadership styles and outcomes were compared with European Reference Scores (ERS) using two-sided one-sample t-tests.
\end{abstract}

Results: Compared with ERS, head nurses and DoN scored significantly lower $(p<0.001)$ on transformational and transactional leadership styles and significantly higher $(p<0.001)$ on passive-avoidant leadership styles. All leadership outcomes were significantly lower $(p<0.001)$ for head nurses. Similar results, however not statistically significant, were found concerning leadership outcomes of DoN.

Conclusions: Results indicate that passive-avoidant leadership styles are excessively present in contrast to transformational leadership styles in nursing homes. This highlights an urgent need to invest in leadership development. Therefore, future research should focus on interventions for the development of transformational leadership.

Keywords: Leadership, Residential care facilities, Nursing home, Care manager, Nurse, Director of nursing

\section{Background}

Worldwide demographic evolutions affect the organization of health care. Especially nursing homes face daunting challenges to meet present and future care needs $[1,2]$. Firstly, individuals consider a nursing home as a last resort and therefore prefer to live as long as possible in their own home [3]. Consequently, most residents admitted to a nursing home suffer from multiple

\footnotetext{
*Correspondence: poels.joris@gmail.com

${ }^{1}$ Department of Public Health and Primary Care, Academic Centre for Nursing and Midwifery, KU Leuven, Kapucijnenvoer 35, 4th floor, P.B. 7001, 3000 Leuven, Belgium

Full list of author information is available at the end of the article
}

complex conditions and are in need of more assistance $[4,5]$. Secondly, poor work organization, time pressure, high workload, staff shortages and turnover are potential threats to quality of care and patient safety [6-9]. Previous research showed high annualized turnover rates for certified nurse assistants (74.5\%), registered nurses (56.1\%) and licensed practical nurses (51.0\%) in nursing homes [10]. The American Association of Colleges of Nursing predicts by 2025, without appropriate intervention strategies, a shortage of approximately 260,000 registered nurses in the United States [11]. These shortages could negatively affect the number of staff available in nursing homes. Moreover, the Institute of Medicine

(c) The Author(s). 2020 Open Access This article is licensed under a Creative Commons Attribution 4.0 International License, which permits use, sharing, adaptation, distribution and reproduction in any medium or format, as long as you give appropriate credit to the original author(s) and the source, provide a link to the Creative Commons licence, and indicate if changes were made. The images or other third party material in this article are included in the article's Creative Commons licence, unless indicated otherwise in a credit line to the material. If material is not included in the article's Creative Commons licence and your intended use is not permitted by statutory regulation or exceeds the permitted use, you will need to obtain permission directly from the copyright holder. To view a copy of this licence, visit http://creativecommons.org/licenses/by/4.0/ The Creative Commons Public Domain Dedication waiver (http://creativecommons.org/publicdomain/zero/1.0/) applies to the data made available in this article, unless otherwise stated in a credit line to the data. 
reports financial and work environment related challenges, such as low wages and job dissatisfaction, in the recruitment and retention of direct-care workers [12]. In addition, both intention to leave and to stay among nurses are associated with leadership practices [13]. In general, literature increasingly describes leadership as a key factor in solving challenges in health care. Northouse (2013) defines leadership as 'a process whereby an individual influences a group of people in order to achieve a common goal'. Its contribution is considered equally important in enhancing the quality of care as in a complex and high risk environment like aviation [14, 15]. For example, when staff perceives leadership as good it positively influences their retention and job satisfaction $[13,16]$.

Leaders can exhibit a variety of leadership styles, characterized by behavioral dimensions. Task-oriented leadership focuses on coordinating and assigning work to followers. Change-oriented leadership aims at the identification, envisioning and managing of change on team level. Relation-oriented leadership comprises of team development and support $[17,18]$. In particular, the Full Range of Leadership Model (FRLM) of Avolio and Bass provides a broad perspective on leadership styles. The first leadership style, transformational leadership, motivates followers to do more than what is expected of them. This leadership style aims to increase the levels of motivation and morality among followers, by invoking idealized influence, individualized consideration, inspirational motivation and. Intellectual stimulation. Firstly, Idealized influence comprises two subcomponents: 1) Idealized influence attributed describes the extent to which a leader works on trusting relationships, whereas 2) idealized influence behavior focuses on the degree to which a leader acts with integrity and works on a collective mission. Secondly, individual consideration measures the extent to which a leader supports and coaches group members. Thirdly, inspirational motivation is measured to gain insight in the extent to which a leader motivates followers with an inspiring vision. Fourthly, intellectual stimulation measures the degree that a leader appeals on the abilities of employees to identify problems and to approach these problems creatively. Transformational leadership will often result in performance that surpasses the expected outcomes [19]. The second leadership style, transactional leadership, emphasizes the exchange relationship between leader and follower; both encouraged to meet their own needs. Transactional leadership has two components: 1) contingent reward refers to clarifying roles and tasks, and providing followers with material or psychological rewards contingent on the fulfillment of obligations; 2) active management by exception refers to a leader actively monitoring the work of followers so that, in case of errors, corrective actions can be undertaken. Transactional leadership will often result in expected outcomes [19]. Finally, the third leadership style, passive-avoidant leadership, consists of two components: 1) passive management-byexception, reflecting avoidance of leadership, and 2) laissez-faire, which means absence of leadership [15, 20]. In addition to measuring leadership styles, the FRLM provides a questionnaire (the MLQ-5X) that also includes nine questions on three outcomes of leadership behavior. The first leadership outcome, extra effort, measures how often followers perceive their leader as someone that motivates others to do more, heightens desires to succeed and increases willingness to try harder. The second, effectiveness, reflects how successful a leader interacts at different levels of the organization, representing a group to higher authorities and meeting others' job-related needs. The third, satisfaction, measures whether followers are satisfied with their leader's working methods [21].

The most recommended style of relation-oriented leadership, included in the FRLM, is transformational leadership [17]. Focusing on the development and implementation of change, this leadership style motivates followers to perform beyond what is expected of them [19, 22]. Literature suggests a link between transformational leadership and several factors. In terms of workforce outcomes, transformational leadership is associated with increased staff-wellbeing, higher job satisfaction, decreased intention to leave and decreased burn-out rate [23-25]. One study shows a direct negative relation between burn-out and transformational leadership ( $\beta=-$ $0.19, p<0.01)$ [26]. This leadership style also positively correlates with patient outcomes such as higher patient satisfaction, higher quality of care, lower mortality and less medication errors [27, 28]. Lastly, transformational leadership relates to organizational outcomes such as increased innovation capacity [29]. Although the potential of transformational leadership in health care is well described, the empiric literature on leadership styles in nursing homes often remains conceptually unclear. Apart from a few studies that suggest the importance of relation-oriented leadership, the leadership styles measured in nursing homes frequently are a black box to be unravelled [30, 31]. Given the need of transformational leadership as an indispensable element in developing, implementing and sustaining the crucial changes that health care needs to make to improve quality of care and patient safety, this study aims to explore leadership styles in nursing homes based on well-described concepts [32, 33]. In addition, this study will also explore outcomes of the present leadership styles. 


\section{Methods}

This study was reported following the STROBE guidelines for observational studies [34].

\section{Sample, setting and design}

A cross-sectional analysis was conducted on baseline data of an ongoing cohort study in 2015 comprising a convenience sample of staff in six nursing homes in Belgium. Nursing homes were included if the managing board agreed to participate, but were excluded if they already participated in another study. Participating staff had to speak and read Dutch. The Medical Ethics Committee of the University Hospitals Leuven approved this study with EC number S52526. All participating staff provided informed consent by voluntarily completing the data collection.

\section{Procedure}

In every nursing home, a moment was scheduled in which staff completed a survey, rating leadership styles of their direct supervisor. Two levels of leadership were examined (Fig. 1). The first level involved the leadership of head nurses, who plan, coordinate, monitor, control and adjust the activities on their ward in order to ensure that staff can deliver individualized care in optimal conditions $[35,36]$. The second level involved the leadership of directors of nursing (DoN), who are continuously balancing between clinical leadership and managerial targets. DoN have a complex role in budgets and finances, staff recruitment, handling staff conflicts, monitoring of care quality and representation to other organizations [37]. Head nurses were rated by at least five staff members working on their ward. DoN were rated by all head nurses in the respective nursing home. Some staff reported to work throughout the entire nursing home and did not solely belong to one ward. They report directly to the DoN and therefore rated the DoN as their direct supervisor. Participants had to master Dutch and participate voluntarily.

\section{Measures}

A validated Dutch version of the Multifactor Leadership Questionnaire 5X (MLQ-5X) form was used to measure leadership styles and outcomes of head nurses and DoN [21]. The MLQ-5X comprises 45 items divided into nine subscales to capture a broad range of leadership behaviors. Items are scored using a five-point Likert scale with responses that range from "never" (0) to "frequently, if not always" [4]. They reflect the degree to which certain leadership behaviors are present and are based on the components of the Full Range of Leadership Model (FRLM) of Avolio and Bass [21]. The FRLM is a wellestablished model, supported by the accumulation of evidence on its validity throughout 30 years [38]. Transformational, transactional and passive avoidant leadership styles, respectively ranked from higher to lower effectivity, are included in the model [19]. Previous research confirmed adequate construct and predictive

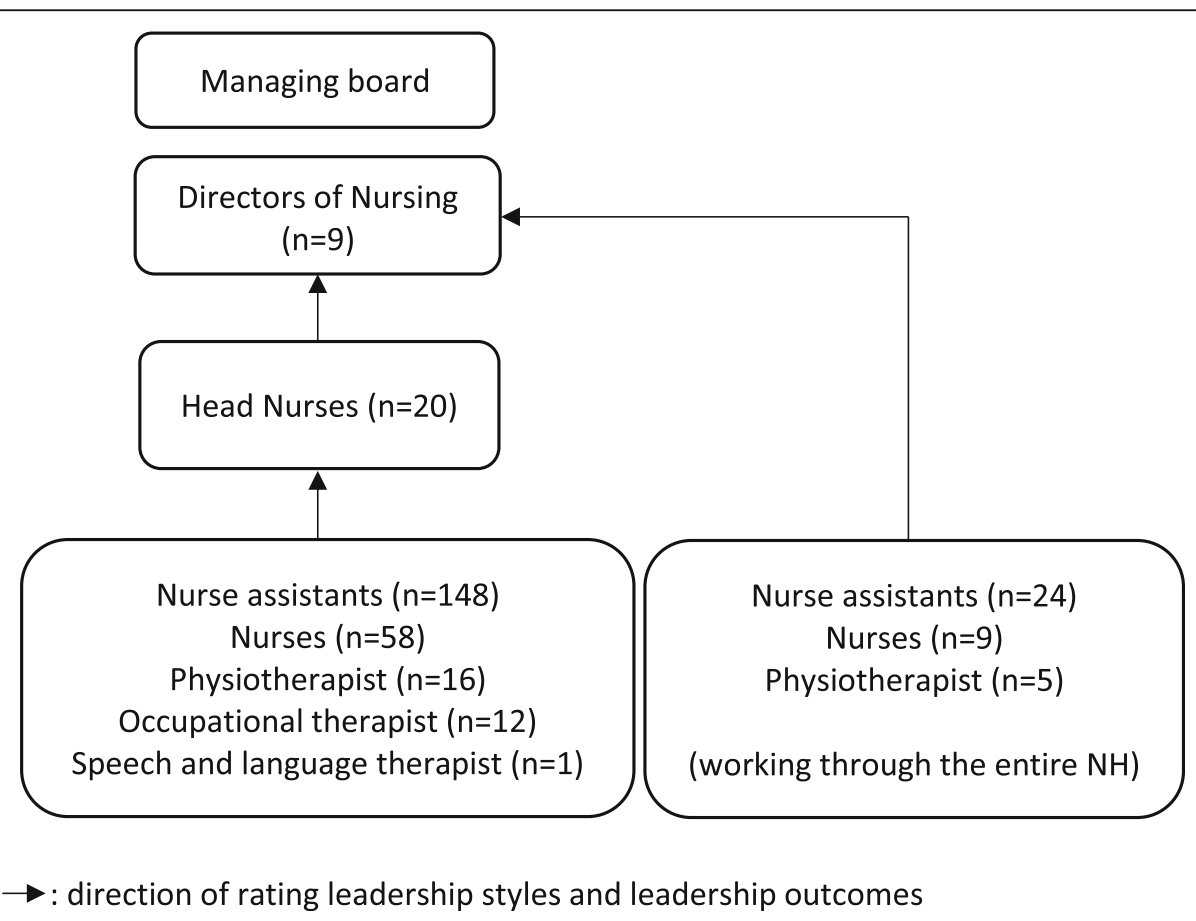

Fig. 1 Rating of leadership styles and leadership outcomes by staff in nursing home: direction of rating leadership styles and leadership outcomes 
validity of the MLQ-5X in that it satisfies the model fit requirement. In addition, based on factorial invariance tests to study the model's consistency, previous research confirmed the reliability of the MLQ-5X in that it measures the same constructs across multiple groups [39]. To interpret the acquired data the MLQ-5X manual provides a scoring key that indicates which scale items should be grouped. Transformational, transactional and passive avoidant leadership are respectively measured by twenty, eight and eight items. For leadership outcomes, which can be considered as results of leadership behavior, extra effort, effectiveness and satisfaction are respectively measured by three, four and two items [21]. Because of copyright stipulations, more detailed information about the questionnaire, scoring key and which items are related to which leadership style is provided in the MLQ-5X Manual [21].

\section{Analysis}

Analysis were performed using SPSS version 22.0 (IBM SPSS, Armonk, NY: IBM Corp.). Analysis were performed for leadership styles of head nurses and DoN in the overall sample. For each component of the FRLM means were calculated. Using a two-sided one-sample ttest, means were compared with the European Reference Scores (ERS), which are normative scores for leadership styles and outcomes based on cross-cultural research [21]. Scores of head nurses and DoN were compared to norm scores for their respective levels, based on normative samples of respectively 3061 and 1222 respondents with a high executive or senior staff function [21]. To correct for multiple testing, a Bonferroni-adjustment was used, setting the significance threshold at $\alpha=0.002$ [40]. A Pearson product-moment correlation coefficient was calculated for each FRLM-component. Cronbach's alpha was used to test the internal consistency of the MLQ-5X subscales, considering a value of $\geq 0.80$ as good and $<0.60$ as poor [41].

\section{Results}

\section{Head nurses}

In total 242 staff received the questionnaires on leadership styles and outcomes of 22 head nurses of which 235 completed these questions (response rate: 97.1\%). Respondents are mainly female (91.5\%), with a mean age of 38.1 years $( \pm 12.1 \mathrm{y})$ and work on average 10 years in the current nursing home $( \pm 10.1 \mathrm{y})$. They work as nurseassistant (63.0\%), nurse (24.7\%), physiotherapist (6.8\%), occupational therapist (5.1\%) and general practitioner $(0.4 \%)$, with a mean number of $28.3 \mathrm{~h}( \pm 10.6 \mathrm{~h})$ per week. Table 1 shows that, compared with the European Reference Scores (ERS), staff rates their direct leaders significantly lower $(p<0.001)$ on four out of five components of transformational leadership: idealized influence attributed, idealized influence behavior, inspirational motivation, intellectual stimulation and individual consideration. Staff rates contingent reward, being part of transactional leadership, also significantly lower $(p<$ 0.001 ) in head nurses, whereas passive-avoidant leadership scores are significantly higher $(p<0.001)$.

Staff scores head nurses significantly lower on all leadership outcomes $(p<0.001)$, compared with the ERS (see Table 2). Intercorrelations of MLQ-subscales are consistent with findings in the European normative sample.

\section{Directors of nursing}

Twenty head nurses and 38 other staff rated leadership styles and outcomes of 9 DoN (see Fig. 1). Respondents are mainly female (93.1\%), with a mean age of 42.2 year $( \pm 9.3 \mathrm{y})$ and work on average 11.8 years $( \pm 9.9 \mathrm{y})$ in the current nursing home. They work as head nurse (34.5\%), night nurse-assistant (41.4\%), night nurse $(15.5 \%)$ and physiotherapist $(8.6 \%)$ with a mean number of $28.3 \mathrm{~h}( \pm$ $10.6 \mathrm{~h})$ per week. Table 3 shows that, compared with the ERS, DoN score significantly lower on idealized influence attributed and individual consideration $(p<0.001)$ whereas passive-avoidant leadership scores are significantly higher $(\mathrm{p}<0.001)$.

No significant results are found in outcomes of leadership in DoN (see Table 4). Intercorrelations of MLQsubscales are consistent with findings in the European normative sample.

\section{Reliability of the MLQ-5X}

Cronbach's alpha was used to test the reliability of the MLQ-5X subscales in both raters of head nurses and DoN (see Tables 1, 2, 3, and 4). With regard to raters of head nurses, internal consistency of scale items is poor for idealized influence attributed $(\alpha=0.48)$ and passive management by exception $(\alpha=0.54)$. In raters of DoN internal consistency is poor for idealized influence $(\alpha=$ $0.42)$, active $(\alpha=0.06)$ and passive management by exception $(\alpha=0.56)$. Cronbach's alpha enhances only in the subscale idealized influence attributed if the item that considers transcending self-interest was deleted in both head nurses $(\alpha=0.77)$ and $\operatorname{DoN}(\alpha=0.73)$.

\section{Discussion}

To the best of our knowledge, this is the first study that quantitatively investigates and maps leadership styles and leadership outcomes of head nurses and directors of nursing (DoN) in nursing homes. Compared with the European Reference Scores (ERS), head nurses and DoN score significantly lower $(p<0.001)$ on components of transformational and transactional leadership, but score significantly higher $(p<0.001)$ on passive-avoidant leadership. In addition, head nurses score significantly lower 


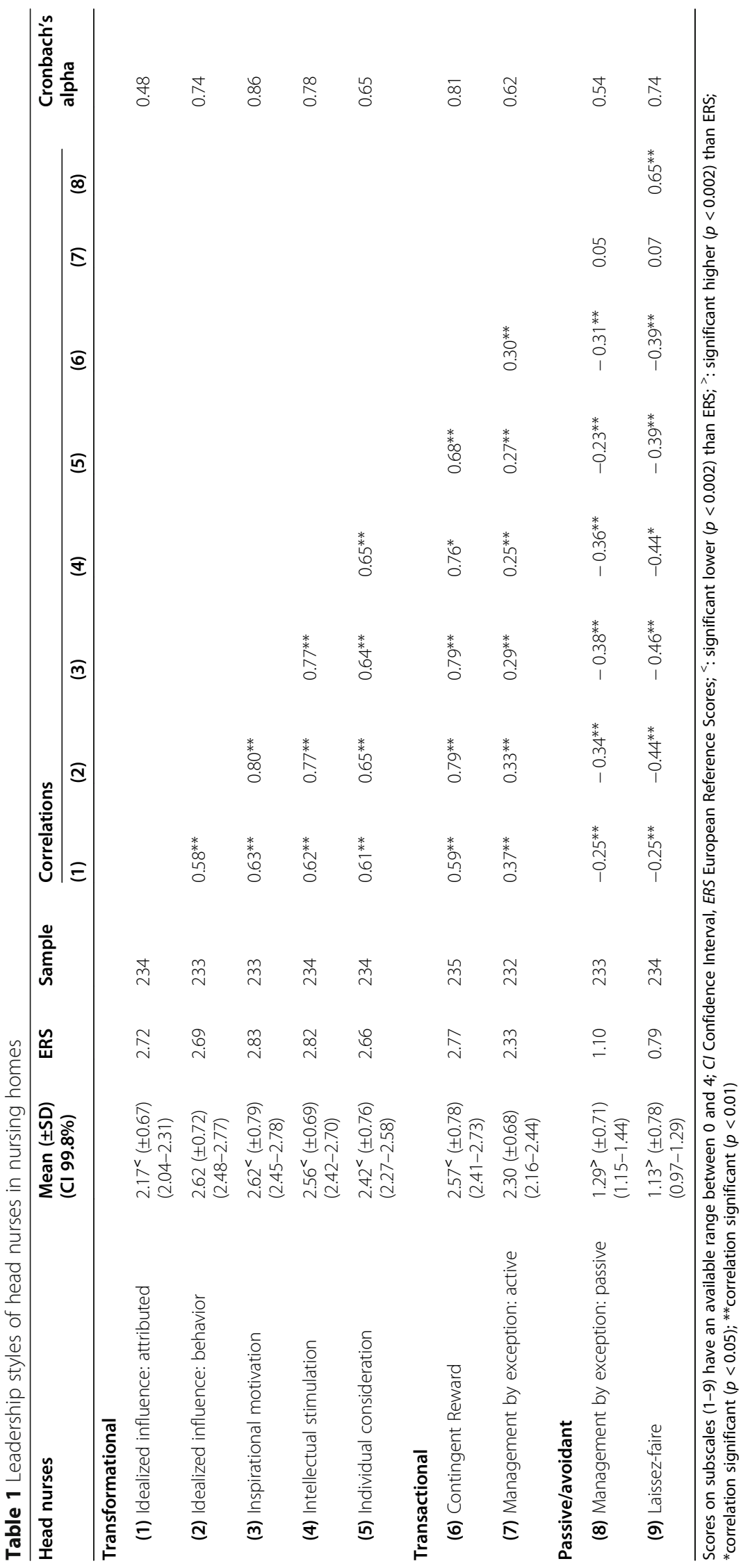


Table 2 Leadership outcomes of head nurses in nursing homes

\begin{tabular}{|c|c|c|c|c|c|c|}
\hline \multirow[t]{2}{*}{ Head nurses } & \multirow{2}{*}{$\begin{array}{l}\text { Mean }( \pm \text { SD) } \\
\text { (Cl 99.8\%) }\end{array}$} & \multirow[t]{2}{*}{ ERS } & \multirow[t]{2}{*}{ Sample } & \multicolumn{2}{|c|}{ Correlations } & \multirow{2}{*}{$\begin{array}{l}\text { Cronbach's } \\
\text { alpha }\end{array}$} \\
\hline & & & & (1) & (2) & \\
\hline (1) Extra Effort & $\begin{array}{l}2.43^{<}( \pm 0.79) \\
(2.27-2.59)\end{array}$ & 2.75 & 231 & & & 0.79 \\
\hline (2) Effectiveness & $\begin{array}{l}2.64^{<}( \pm 0.72) \\
(2.49-2.79)\end{array}$ & 3.01 & 232 & $0.77^{* *}$ & & 0.84 \\
\hline (3) Satisfaction & $\begin{array}{l}2.67^{<}( \pm 0.83) \\
(2.50-2.84)\end{array}$ & 2.94 & 231 & $0.75^{* *}$ & $0.83^{* *}$ & 0.72 \\
\hline
\end{tabular}

Scores on subscales (1-3) have an available range between 0 and 4; $C l$ Confidence Interval; ERS European Reference Scores; ${ }^{<}$significant lower ( $\left.p<0.002\right)$ than ERS; ': significant higher $(p<0.002)$ than ERS; ${ }^{*}$ correlation significant $(p<0.05) ;{ }^{* *}$ correlation significant $(p<0.01)$

than ERS on all leadership outcomes $(p<0.001)$. Similar results, however not statistically significant, are found concerning leadership outcomes of DoN. Previous research on leadership styles in nursing homes found that, based on the Bonoma-Slevin leadership model, an autocrat style was used by $25 \%$ of DoN. An autocrat leader does not involve, nor informs employees about decisions [42]. In addition, results showed that a consensus leadership style, that involves employees and encourages team decision making, was used by only $30 \%$ of DoN $[42,43]$. Given the potential influences on care quality and patient safety, our results, showing low scores on transformational leadership styles and high scores on passiveavoidant leadership styles, are alarming. Several aspects may contribute to our study results. First, nursing leadership often seems to be conflated with administrative positions. Therefore, head nurses may not be able to lead staff if their available time is filled with administrative tasks that hinder a visible presence on their wards. Consequently, the low scores on leadership outcomes may reflect some dissatisfaction of staff with the current 'absence' and 'avoidance' of leadership [44]. Although leadership styles may be context dependent, previous research investigating characteristics of highly rated leadership confirmed non-avoidant and non-passive behaviors such as coaching, closely monitoring of work and giving direct feedback (i.e. being visible) as crucial in nursing home leaders [45]. Furthermore, this is also consistent with previous findings in hospitals, a leader that is perceived as 'good' by staff may be one that is visible [46]. Similarly, to effectively provide guidance to the nursing home managing board, DoN need to remain closely in contact with staff. Their recommendations should include issues and perspectives of staff (e.g. head nurses) 'on the front line' [47]. Second, there could be a discrepancy between the expected leadership and the perceived leadership of staff. Expectations of leadership are influenced by various factors, like for example education. Nurse-assistants and head nurses often have a different educational background possibly influencing their conceptions of leadership [48, 49]. Third, due to rising demands and limited resources, DoN and head nurses in nursing homes are confronted with a conflict between management targets and optimal care delivery. In order to cope with these contradictory circumstances they may use avoidance as a survival strategy [50]. Consequently, staff may perceive absent, passive-avoidant leadership. However, in previous research leadership was described as flexible, creative and supportive by staff in highperforming nursing homes and as out-of-touch in lowperforming nursing homes [30]. A recent systematic review confirms the negative influence of passive-avoidant leadership styles such as management by exception and laissez-faire leadership on staff satisfaction with work, job and their leaders, staff health and wellbeing, staff productivity and effectiveness, highlighting the importance of the findings in our study [13].

\section{Strengths of the study}

This study seems unique, because it quantitatively investigates and maps leadership styles and leadership outcomes on different levels in nursing homes. Second, previous research in nursing homes concerning leadership is often limited to the measurement of transformational leadership styles. However, this study includes all leadership styles of the FRLM, enabling a broader insight. Third, the extension of the MLQ-5X concerning leadership outcomes is included, providing insight in results of leadership styles. Fourth, a stringent Bonferroniadjustment is applied to the alpha-level $(p<0.002)$ to minimize the risk of reporting a statistically significant difference while this is actually not present. Fifth, selfratings are often used to measure leadership. However, considering the potential influence of leadership on staff performance, in our study, leaders are rated by their staff to avoid self-serving bias through self-ratings $[13,51]$.

\section{Limitations of the study}

Some limitations warrant further notice. First, the available European Reference Scores (ERS) for the MLQ-5X are not specific for the context of health care. They were derived from higher executive levels of leadership, limiting their suitability for use in nursing homes [21]. Therefore, the comparison of scores between a group of 


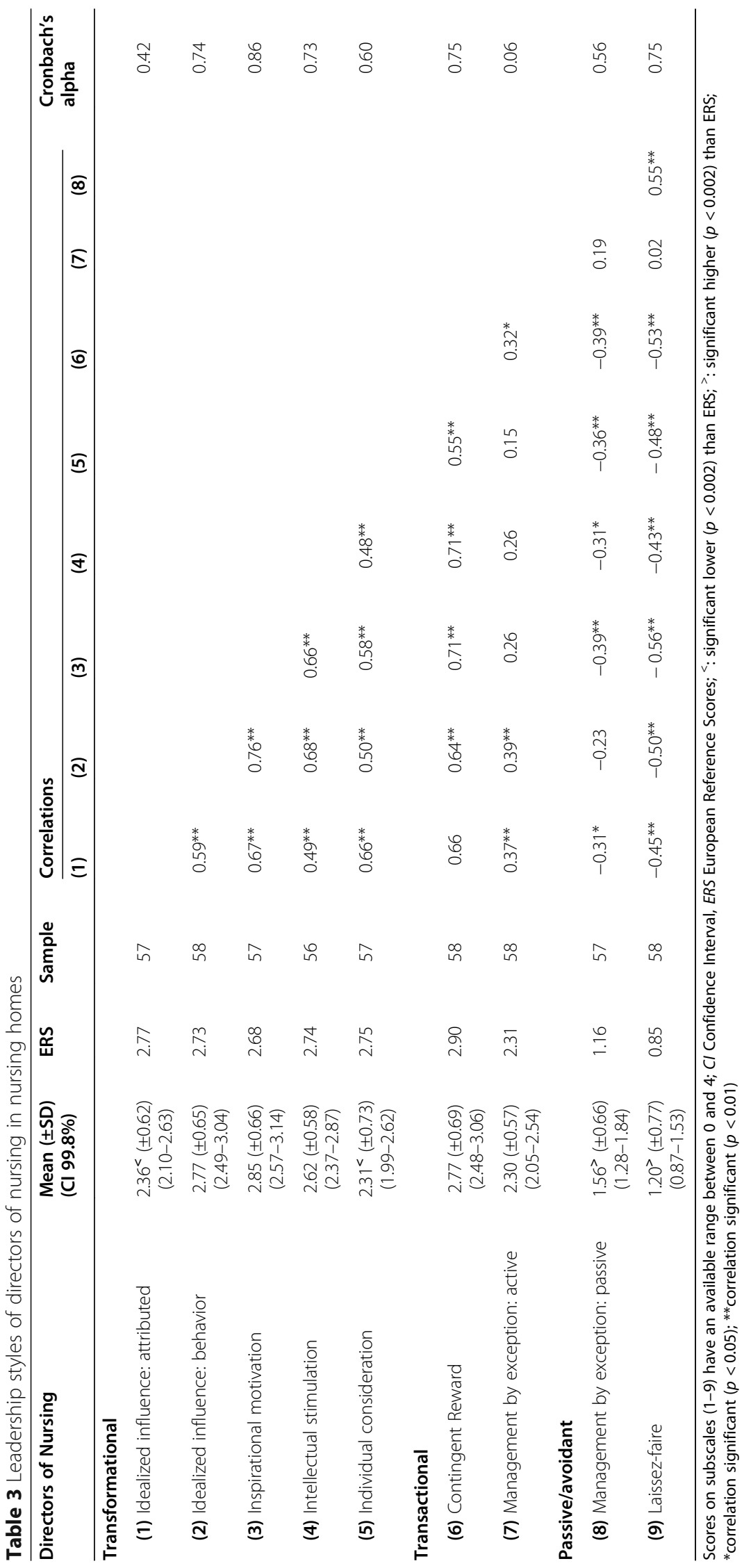


Table 4 Leadership outcomes of directors of nursing in nursing homes

\begin{tabular}{|c|c|c|c|c|c|c|}
\hline \multirow{2}{*}{$\begin{array}{l}\text { Directors of } \\
\text { Nursing }\end{array}$} & \multirow{2}{*}{$\begin{array}{l}\text { Mean }( \pm S D) \\
(\mathrm{Cl} 99.8 \%)\end{array}$} & \multirow[t]{2}{*}{ ERS } & \multirow[t]{2}{*}{ Sample } & \multicolumn{2}{|c|}{ Correlations } & \multirow{2}{*}{$\begin{array}{l}\text { Cronbach's } \\
\text { alpha }\end{array}$} \\
\hline & & & & (1) & (2) & \\
\hline (1) Extra Effort & $\begin{array}{c}2.54( \pm 0.74) \\
(2.22-2.86)\end{array}$ & 2.66 & 56 & & & 0.73 \\
\hline (2) Effectiveness & $\begin{array}{l}2.78( \pm 0.63) \\
(2.51-3.05)\end{array}$ & 2.96 & 56 & $0.74^{* *}$ & & 0.76 \\
\hline (3) Satisfaction & $\begin{array}{c}2.86( \pm 0.74) \\
(2.54-3.18)\end{array}$ & 2.92 & 57 & $0.69^{* *}$ & $0.83^{* *}$ & 0.86 \\
\hline
\end{tabular}

Scores on subscales (1-3) have an available range between 0 and 4; $C l$ Confidence Interval, ERS European Reference Scores; ${ }^{<}$significant lower $(p<0.002)$ than ERS; ': significant higher $(p<0.002)$ than ERS; ${ }^{*}$ correlation significant $(p<0.05) ;{ }^{* *}$ correlation significant $(p<0.01)$

executives (i.e. the ERS) and head nurses in nursing homes should be interpreted with caution. European Reference Scores for leadership in health care settings could support a more accurate comparison. Second, compared with the sample size for raters of head nurses, the small sample size for raters of DoN may limit the generalizability of the results. However, this likely reflects the organizational proportions of functions in nursing home staff. Third, the use of a convenience sample may also limit generalizability. Fourth, the small sample size does not allow comparisons of leadership styles between nursing homes, hindering further subgroup analysis. Fifth, in this descriptive study participants rated leadership styles of their direct leader using the well-established MLQ-5X questionnaire [21]. More nursing home outcome data would need to be evaluated to make more declarative statements of the value of different leadership styles and outcomes. Furthermore, additional qualitative data could have provided a deeper understanding of the results.

\section{Implications for research}

First, although the MLQ-5X visualizes a broad range of leadership styles, reliability analysis reveal poor Cronbach's alpha values for some subscales. This possibly indicates unsuitability of conceptualizations for the relevant items. Therefore, future research should focus on the development of an instrument specifically designed to measure leadership in the context of nursing homes. Second, given our results, future research should focus on developing interventions to convert passiveavoidant leadership styles to transformational styles on different levels within nursing homes.

\section{Implications for practice}

The presence of passive-avoidant leadership styles in nursing homes may negatively influence their resilience to face the predicted daunting challenges. On the one hand, the constraints present in nursing homes may hinder the development of well-established transformational leadership in head nurses and DoN. On the other hand, passive-avoidant and transactional leadership styles are unlikely to meet the complex demands in this context. The well-known paradox of meeting more needs with fewer resources makes the necessity for effective interventions on leadership and leadership development in nursing homes undeniable. Effective interventions specific to nursing homes currently seem to be lacking, however the participation of head nurses and DoN in existing programs on leadership development could be an important first step.

\section{Conclusions}

Our study describes that passive-avoidant leadership styles are excessively present in contrast to transformational leadership styles in nursing homes. Given the importance of leadership to face current and future challenges, these findings indicate an urgent need to invest in leadership development in nursing homes. To promote transformational leadership, future research should focus on interventions for leadership development. Prior to this, an instrument to measure leadership in the specific context of nursing homes should be developed. This instrument could in turn support the development of transformational leadership in nursing homes.

\section{Abbreviations}

DoN: Director of Nursing; ERS: European Reference Scores; FRLM: Full Range of Leadership Model; MLQ-5X: Multifactor Leadership Questionnaire 5X; $\mathrm{NH}$ : Nursing home

\section{Acknowledgements}

The authors would like to thank Mind Garden Inc. for giving permission to use the Multifactor Leadership Questionnaire form 5X, developed by Bruce Avolio and Bernard Bass.

Authors' contributions

Design of the study: JP, MV, KM and EV. Data collection and analysis: JP and EV. Interpretation: JP, MV, KM and EV. Drafting the manuscript: JP. Critical revisions, revisions and approval of final manuscript: JP, MV, KM and EV. Supervision: EV. The author(s) read and approved the final manuscript.

\section{Funding}

This study was supported by the Flemish Ministry of Welfare, Public Health and Family. The Flemish Ministry of Welfare, Public Health and Family did not play a role in the elaboration of this study. 


\section{Availability of data and materials}

The datasets used and/or analysed during the current study are available from the corresponding author on reasonable request.

\section{Ethics approval and consent to participate}

The Medical Ethics Committee of the University Hospitals Leuven approved this study with EC number S52526. Written consent was provided at the nursing home level by the managing board. All participating staff gave informed consent by voluntarily completing the questionnaires. The ethics committee approved this procedure for obtaining informed consent.

\section{Consent for publication}

Not applicable.

\section{Competing interests}

The authors declare that they have no competing interests.

\section{Author details}

'Department of Public Health and Primary Care, Academic Centre for Nursing and Midwifery, KU Leuven, Kapucijnenvoer 35, 4th floor, P.B. 7001, 3000 Leuven, Belgium. ${ }^{2}$ Development \& Education, University Hospitals Leuven, Leuven, Belgium. ${ }^{3}$ Department of Internal Medicine, Division of Geriatric Medicine, University Hospitals Leuven, Leuven, Belgium.

Received: 28 May 2020 Accepted: 22 October 2020

Published online: 04 November 2020

\section{References}

1. Sorbe S. Belgium: enhancing the cost efficiency and flexibility of the health sector to adjust to population ageing. Brussels: OECD Publishing; 2013.

2. He W, Goodkind D, Kowal PR. An aging world: 2015: United States Census Bureau; 2016.

3. Hajek A, Brettschneider C, Lange C, Posselt T, Wiese B, Steinmann S, et al. Longitudinal predictors of institutionalization in old age. PLoS One. 2015; 10(12):e0144203.

4. Moore KL, Boscardin WJ, Steinman MA, Schwartz JB. Age and sex variation in prevalence of chronic medical conditions in older residents of U.S. nursing homes. J Am Geriatr Soc. 2012;60(4):756-64.

5. Young Y, Kalamaras J, Kelly L, Hornick D, Yucel R. Is Aging in Place Delaying Nursing Home Admission? J Am Med Dir Assoc. 2015;16(10):900.e1-6.

6. Zúñiga F, Ausserhofer D, Hamers JPH, Engberg S, Simon M, Schwendimann R. Are staffing, work environment, work stressors, and rationing of care related to care Workers' perception of quality of care? A cross-sectional study. J Am Med Dir Assoc. 2015;16(10):860-6.

7. Castle NG, Ferguson-Rome JC. Influence of nurse aide absenteeism on nursing home quality. The Gerontologist. 2015;55(4):605-15.

8. Castle NG, Anderson RA. Caregiver staffing in nursing homes and their influence on quality of care: using dynamic panel estimation methods. Med Care. 2011;49(6):545-52.

9. Hyer K, Thomas KS, Branch LG, Harman JS, Johnson CE, Weech-Maldonado R. The influence of nurse staffing levels on quality of Care in Nursing Homes. The Gerontologist. 2011;51(5):610-6.

10. Donoghue C. Nursing home staff turnover and retention. J Appl Gerontol. 2010;29(1):89-106.

11. Nursing AAoCo. Nursing Shortage Fact Sheet 2017 [updated 18/05/2017]. Available from: http://www.aacn.nche.edu/media-relations/NrsgShortageFS. pdf.

12. Medicine lo. Retooling for an aging America: building the health care workforce. Washington: The National Academies Press; 2008. p. 316.

13. Cummings GG, Tate K, Lee S, Wong CA, Paananen T, Micaroni SPM, et al. Leadership styles and outcome patterns for the nursing workforce and work environment: a systematic review. Int J Nurs Stud. 2018;85:19-60.

14. Gluck PA. Patient safety: some progress and many challenges. Obstet Gynecol. 2012;120(5):1149-59.

15. Northouse PG. Leadership: theory and practice: sage; 2012.

16. Donoghue C, Castle NG. Leadership styles of nursing home administrators and their association with staff turnover. The Gerontologist. 2009;49(2):166-74.

17. Sellgren SF, Ekvall G, Tomson G. Leadership behaviour of nurse managers in relation to job satisfaction and work climate. J Nurs Manag. 2008;16(5):578-87.
18. Yukl G, Gordon A, Taber T. A hierarchical taxonomy of leadership behavior: integrating a half century of behavior research. J Leadership Organ Stud. 2002;9(1):15-32.

19. Bass BM, Avolio BJ. Improving organizational effectiveness through transformational leadership: sage; 1994.

20. Bass BM. Two decades of research and development in transformational leadership. Eur J Work Org Psychol. 1999;8(1):9-32.

21. Avolio BJ, Bass BM. Multifactor leadership questionnaire (MLQ). Mind Garden 2004

22. Lin P-Y, MacLennan S, Hunt N, Cox T. The influences of nursing transformational leadership style on the quality of nurses' working lives in Taiwan: a cross-sectional quantitative study. BMC Nurs. 2015;14(1):33.

23. Rokstad AMM, Vatne S, Engedal K, Selbæk G. The role of leadership in the implementation of person-centred care using dementia care mapping: a study in three nursing homes. J Nurs Manag. 2015;23(1):15-26.

24. Cowden T, Cummings G, Profetto-McGrath J. Leadership practices and staff nurses' intent to stay: a systematic review. J Nurs Manag. 2011;19(4):461-77.

25. Weberg D. Transformational leadership and staff retention: an evidence review with implications for healthcare systems. Nurs Adm Q. 2010;34(3): 246-58.

26. Cheng C, Cheng C, Bartram T, Bartram T, Karimi L, Karimi L, et al. Transformational leadership and social identity as predictors of team climate, perceived quality of care, burnout and turnover intention among nurses. Pers Rev. 2016;45(6):1200-16.

27. Wong CA, Cummings GG, Ducharme L. The relationship between nursing leadership and patient outcomes: a systematic review update. J Nurs Manag. 2013;21(5):709-24.

28. Spence Laschinger HK, Wong CA, Grau AL, Read EA, Pineau Stam LM. The influence of leadership practices and empowerment on Canadian nurse manager outcomes. J Nurs Manag. 2012;20(7):877-88.

29. García-Morales VJ, Jiménez-Barrionuevo MM, Gutiérrez-Gutiérrez L. Transformational leadership influence on organizational performance through organizational learning and innovation. J Bus Res. 2012;65(7): 1040-50.

30. Forbes-Thompson S, Leiker T, Bleich MR. High-performing and lowperforming nursing homes: a view from complexity science. Health Care Manag Rev. 2007;32(4):341-51.

31. Anderson RA, Issel LM, McDaniel RR. Nursing homes as complex adaptive systems: relationship between management practice and resident outcomes. Nurs Res. 2003;52(1):12-21.

32. Marshall ES, Broome ME. Transformational leadership in nursing: from expert clinician to influential leader: springer publishing company; 2016.

33. McFadden KL, Stock GN, Gowen CR 3rd. Leadership, safety climate, and continuous quality improvement: impact on process quality and patient safety. J Nurs Admin. 2014;44(10 Suppl):S27-37.

34. Von Elm E, Altman DG, Egger M, Pocock SJ, Gøtzsche PC, Vandenbroucke JP. The Strengthening the Reporting of Observational Studies in Epidemiology (STROBE) Statement: Guidelines for reporting observational studies. Int J Surg. 2014;12(12):1495-9.

35. Belgisch Staatsblad. Koninklijk besluit houdende uitvoering van artikel 17bis van de wet op de ziekenhuizen, gecoördineerd op 7 augustus 1987, voor wat de functie van hoofdverpleegkundige betreft 2006. Available from: http://www.ejustice.just.fgov.be/cgi_loi/change_lg.pl?language=nl\&la= $N \& c n=1987080732 \&$ table_name=wet.

36. Venturato L, Drew L. Beyond 'doing': supporting clinical leadership and nursing practice in aged care through innovative models of care. Contemp Nurse. 2010;35(2):157-70.

37. Backman A, Sjögren K, Lindkvist M, Lövheim H, Edvardsson D. Towards person-centredness in aged care-exploring the impact of leadership. J Nurs Manag. 2016;24(6):766-74.

38. Antonakis J, House RJ. The Full-Range Leadership Theory: The Way Forward. Transformational and Charismatic Leadership: The Road Ahead 10th Anniversary Edition. Monographs in Leadership and Management: 5. Sommerville: Emerald Group Publishing Limited; 2013. p. 3-33.

39. Antonakis J. The validity of the transformational, transactional, and laissezfaire leadership model as measured by the multifactor leadership questionnaire (MLQ 5X); 2001.

40. Armstrong RA. When to use the Bonferroni correction. Ophthalmic Physiol Opt. 2014;34(5):502-8.

41. DeVellis RF. Scale development: theory and applications: sage publications; 2016. 
42. Castle NG, Decker FH. Top management leadership style and quality of care in nursing homes. The Gerontologist. 2011;51(5):630-42.

43. McKinney SH, Corazzini K, Anderson RA, Sloane R, Castle NG. Nursing home director of nursing leadership style and director of nursing-sensitive survey deficiencies. Health Care Manag Rev. 2016;41(3):224-32.

44. Cutcliffe J, Cleary M. Nursing leadership, missing questions, and the elephant(s) in the room: problematizing the discourse on nursing leadership. Issues in Mental Health Nursing. 2015;36(10):817-25.

45. Backman A, Sjögren K, Lindkvist M, Lövheim H, Edvardsson D. Characteristics of highly rated leadership in nursing homes using item response theory. J Adv Nurs. 2017;73(12):2903-13.

46. Duffield CM, Roche MA, Blay N, Stasa H. Nursing unit managers, staff retention and the work environment. J Clin Nurs. 2011;20(1-2):23-33.

47. Davies N. Visible leadership: going back to the front line. Nurs Manag. 2013; 20(4):22-6.

48. Schyns B, Schilling J. Implicit leadership theories: think leader, think effective? J Manag Inq. 2011;20(2):141-50.

49. Rush MC, Thomas JC, Lord RG. Implicit leadership theory: a potential threat to the internal validity of leader behavior questionnaires. Org Behav Human Perform. 1977;20(1):93-110

50. Jackson D, Hutchinson M, Peters K, Luck L, Saltman D. Understanding avoidant leadership in health care: findings from a secondary analysis of two qualitative studies. J Nurs Manag. 2013;21(3):572-80.

51. Fleenor JW, Smither JW, Atwater LE, Braddy PW, Sturm RE. Self-other rating agreement in leadership: a review. Leadersh Q. 2010;21(6):1005-34.

\section{Publisher's Note}

Springer Nature remains neutral with regard to jurisdictional claims in published maps and institutional affiliations.

Ready to submit your research? Choose BMC and benefit from:

- fast, convenient online submission

- thorough peer review by experienced researchers in your field

- rapid publication on acceptance

- support for research data, including large and complex data types

- gold Open Access which fosters wider collaboration and increased citations

- maximum visibility for your research: over $100 \mathrm{M}$ website views per year

At BMC, research is always in progress.

Learn more biomedcentral.com/submissions 